\title{
Prof dr J H Koekemoer as kerkman en akademikus
}

\author{
P J van der Merwe \\ Departement Godsdiens- en Sendingwetenskap \\ Universiteit van Pretoria
}

\begin{abstract}
Prof Dr J H Koekemoer in service of church and university

Prof Johannes Hendrik Koekemoer's career as minister of the Nederduitsch

Hervormde Kerk started in 1960. In 1989 he became a full member and in 1992 Dean of the Faculty of Theology (Section A), Universiteit of Pretoria. This second part of his career ended on 31 December 1999 when he retired. He played a major role in the restructuring and amalgamation of the Faculty of Theology. The article reviews his work and contribution in both fields of church and university.
\end{abstract}

\section{VORMING EN OPLEIDING}

Johannes Hendrik Koekemoer is op 27 Augustus 1935 te Losberg in die distrik Potchefstroom gebore as die oudste van drie kinders en enigste seun. As lid van 'n bekende Hervormde gesin groei hy op in noue verband met die Hervormde Kerk. Tog is dit interessant dat sy familie aan moederskant meestal tot die Gereformeerde Kerke behoort en dat verskeie neefs van sy moeder, asook van sy eie neefs, predikante in die Gereformeerde Kerke was of is. Dat hulle eie gesin Hervormd gebly het, dui volgens hom op die stoere verbintenis van die Koekemoer-familie met die Hervormde Kerk.

Sy ouers was boere en die plaaslewe was 'n lang ruk sy wêreld, veral waar hy sy laerskoolopleiding ook nog aan 'n skoolplaas ontvang het (Generaal Pienaar-skoolplaas). Sy hoërskoolopleiding het hy aan die Hoër Volkskool te Potchefstroom deurloop waar hy in 1953 matriek behaal het.

Hierna is hy na die Universiteit van Pretoria waar hy in 1956 die BA- en in 1959 die BD-grade voltooi het. In 1959 was daar ook nog geen aanduiding van die Geysersaak 
wat in 1960 sou losgebars nie. Dit het vir hom wat toe reeds Fakulteit verlaat het, as 'n verrassing gekom, aangesien hy prof AS Geyser as 'n uitstekende dosent en uitnemende Nuwe-Testamentikus ervaar het.

\section{IN PASTORALE DIENS}

Op 23 Januarie 1960 word hy georden te Turffontein waar hy nagenoeg vir twee jaar dien.' In dié tydperk tree hy ook in die huwelik met die skone Issie Symington, jongste dogter van wyle dr F C en mev Symington van Pretoria. So begin 'n lang en gelukkige huwelik waaruit drie seuns gebore is. In 1963 vertrek die egpaar na Bethal en in 1965 aanvaar hy 'n beroep na Zuurfontein. Die laaste gemeente wat hy in vaste hoedanigheid bearbei het, was Pretoria-Suid waar hy vanaf 1972 tot 1978 werksaam was. Gedurende hierdie tydperk van sy bediening dien hy telkens op ringskommissies, dikwels as voorsitter. So leer hy die Hervormde Kerk op gemeentevlak goed ken, vanaf die platteland tot in die hoëdigtheidsomgewing van die stad. Hy dien in dié tyd ook op die bestuursrade van verskillende skole.

Intussen was hy ook ingeskryf vir die doktorale studie. Hy promoveer in 1972 onder leiding van prof B J Engelbrecht met 'n proefskrif getitel: "Die Christologie van die Nuwe Teologie - 'n interpretasieprobleem." Ná 1978 het hy voortgegaan om as pastorale hulp in gemeentes te werk, te wete Boksburg, Philadelphia en Villieria. Wanneer die Hervormde Kerk later besluit dat die dosente nie meer as pastorale hulp in gemeentes mag optree nie, berus hy hom daarby, maar waarsku ook dat dié besluit die gevolg kan hê dat die afstand tussen kateder en kansel kan vergroot, tot nadeel van beide kerk en teologie. Teologie in 'n ivoortoring was vir hom ondenkbaar.

\section{IN SINODALE DIENS}

In 1978 besluit die Nederduitsch Hervormde Kerk van Afrika om die Kerklike Instituut vir Toerusting van Ampsdraers en Lidmate (Kital) tot stand te bring. Dit was die gevolg van 'n droom wat by prof J P Oberholzer geleef het en 'n positiewe studieverslag wat deur prof P S Dreyer in opdrag van die Kommissie van die Algemene Kerkvergadering

\footnotetext{
1 Dit beteken dat hy op 23 Januarie 2000 sy veertigjarige ampsjubileum gevier het.
} 
afgehandel het. Kital sou aanvanklik op twee funksies ingestel wees: (1) toerusting van ampsdraers en (2) die organisering van 'n omvangryke versameling van publikasies en die ontsluiting van kerklike dokumentasie (notules, verslae en dies meer).

Dr Koekemoer word as eerste direkteur van Kital aangestel. In 1984 word hy bevorder tot Senior Direkteur, nadat ds P A Geyser en dr M J du P Beukes ook as direkteure tot Kital se bemanning toegevoeg is. Gedurende die tyd wat volg, lei hy Kital tot groei en wasdom. Sy effektiewe organisasie- en bestuursvermoë plaas die Instituut van die staanspoor op ' $n$ stewige basis. Die instelling word 'n belangrike bate vir die Hervormde Kerk met die ontwikkeling en aanbieding van ' $n$ wye spektrum van toerustingskursusse. Om hom vir hierdie taak te help skool, woon hy ook 'n hele aantal kursusse in seminaarbestuur en doelwitbeplanning by. Hy is betrokke by die ontwerp, skryf en aanbieding van 'n dertigtal kursusse vir ampsdraers en lidmate.

In 1978 reeds woon hy die Internasionale Boekeskou in Frankfurt, Duitsland, by waar hy blootgestel word aan die internasionale boekewêreld en die lewendige Europese boekkultuur. Dit spoor hom aan om die leeskultuur plaaslik te bevorder. Kital word onder sy leiding ' $n$ belangrike uitgewer van Christelike en kerklike literatuur. Gedurende sy termyn inisieer of is hy betrokke by nagenoeg 140 publikasies van Kital. Drie boeke verskyn uit sy pen, terwyl hy as eindredakteur van tien boeke optree.

Die Algemene Kerkvergadering besluit vroeg in die tagtigerjare dat die ganse kategeseleergang, asook die reeks van kategesehandboeke, ingrypend hersien moet word en gee aan Kital die opdrag. Dominee Geyser word aanvanklik vir dié doel by Kital aangestel en later ook dr M J du P Beukes. Dit word gedurende die tagtigerjare die vernaamste projek van die Instituut. As Senior Direkteur kon Johan nie anders as om ook daarby betrokke te wees nie.

Voordat hy by Kital aangestel is, word hy reeds in verskillende sinodale rade benoem. Een raad waarvan die herinneringe hom die duidelikste bybly, was die Raad vir Ekumeniese Sake, veral van sy eerste termyn toe hy as jong predikant saam met manne soos dr C J Mans, dr J P Oberholzer, prof B J Engelbrecht, prof J I de Wet en prof A D Pont moes sitting neem. Later word hy uit hoofde van sy sitting op dié raad ook op die Tussenkerklike Kommissie benoem waar hy uiteindelik vyftien jaar dien. 
Hy word ook deur die Kerk ook na verskeie ekumeniese konferensies afgevaardig. Saam met ds Geyser en dr C J Viljoen word hy as 't ware 'n ekumeniese "conference hopper" en ontwikkel hy eerstehandse kennis van die internasionale ekumeniese toneel.

- In 1979 woon hy 'n konferensie van die Wêreldbond van Gereformeerde Kerke in Pretoria by.

- In 1980 woon hy die Gereformeerde Ekumeniese Sinode (GES) in Nimes, Frankryk, by.

- In 1982 die Wêreldbond van Gereformeerde Kerke in Ottawa, Kanada.

- In 1983 die International Council of Christian Churches (ICCC), Cape May, VSA.

- In 1984 die Gereformeerde Ekumeniese Sinode, Chicago, VSA.

Die tagtigerjare was ook die tyd waarin die Hervormde Kerk sy lidmaatskap van die Wêreldbond van Gereformeerde Kerke prysgegee het. Hierna is 'n tydlank oorweeg om by die ICCC in te skakel, maar uiteindelik is op advies van drr Koekemoer en Viljoen daarteen besluit, angesien die kerklike wêreld wat deur dié liggaam verteenwoordig word, te ver van dié van die Hervormde Kerk lê. Die konferensies van die GES het hulle ook nooit anders as waarnemers bygewoon nie, aangesien die Hervormde Kerk ook in dié geval nie vir lidmaatskap kans gesien het nie.

Sy eggenote, Issie, 'n opgeleide bibliotekaris, ontwikkel in hierdie tyd die Kitalbiblioteek en -indeks waarmee nie alleen al die belangrike materiaal van die Hervormde Kerk rekenaarmatig ontsluit word nie, maar ook die mees volledige ekumeniese indeks in Suid-Afrika tot stand kom. ${ }^{2}$ Dit was een van die maniere waarop die Hervormde Kerk steeds sy belang by ekumene uitgeleef het.

Ander rade of kommissies waarvan hy ook lewendige herinneringe koester, is die Raad vir Jeugwerk, die Kuratorium, die Psalmberymingskommissie en die Kommissie van die Algemene Kerkvergadering.

\footnotetext{
2 Ongelukkig is die inskrywing van verskeie belangrike ekumeniese tydskrifte 'n paar jaar gelede gestaak as deel van ' $n$ besparingsveldtog. Daarmee het hierdie versameling sy status as mees volledige ekumeniese versameling in Suid-Afrika verloor.
} 
'n Verdere dimensie is aan sy pos as Senior Direkteur van Kital toegevoeg toe hy ingevolge 'n ooreenkoms met die Universiteit van Pretoria op 1 Januarie 1987 as die eerste direkteur van die nuutgestigte Sentrum vir Voortgesette Teologiese Toerusting (SVTT) aan die Fakulteit Teologie (Afd A) aangestel is. Dit het aan hom die titel van professor besorg, ofskoon sy setel steeds Kital sou bly. 'n Vrugbare tydperk van samewerking tussen Kital en die SVTT het hierna aangebreek. Hy tree in hierdie tyd ook op as medeaanbieder van die radioprogram "Wat sê die Bybel?". Verder het hy aan verskeie televisieuitsendings deelgeneem.

\section{IN DIENS VAN DIE UNIVERSITEIT VAN PRETORIA}

Sy verbintenis met die Universiteit van Pretoria gaan terug na 1978 toe hy as tydelikdeeltydse dosent begin het om prof B J Engelbrecht met die onderrig van Dogmatiek by te staan. Hierdie taak verrig hy ononderbroke vir die volgende elf jaar.

Prof Engelbrecht sou aan die einde van 1988 met pensioen aftree, maar sou die grootste gedeelte van die tweede semester van daardie jaar met verlof wees. Johan word versoek om al sy klasse oor te neem. Kort daarna maak prof G C Velthuysen bekend dat hy die akademiese lewe aan die einde van 1988 vir 'n loopbaan by Perskor gaan verruil, wat sou beteken dat die Departement Dogmatiek en Christelike Etiek met een slag ontruim sou word.

Die Kuratorium besluit hierop om dr J H Koekemoer as professor en hoof van die Departement Dogmatiek en Christelike Etiek aan te beveel en die Kommissie van die Algemene Kerkvergadering het die advies aanvaar. Verskeie van die kerklui het gedink dat hy nie die aanstelling sou aanvaar nie, aangesien predikante in sinodale diens op daardie stadium heelwat hoër salarisse as professore ontvang het. Hy het egter nie gehuiwer om dit wel te doen nie, aangesien hy die verleentheid van die Hervormde Kerk goed begryp het. Op die lang duur het dit ook die regte besluit geblyk te wees. So word hy dan op 1 Januarie 1989 aangestel as professor en hoof van die Departement Dogmatiek en Christelike Etiek aan die Fakulteit Teologie (Afd A), Universiteit van Pretoria. Hy lewer sy intreerede aan die begin van 1989 met die onderwerp: "Dogmatiek binne konfessionele verband." 
Die vertroue wat hy van die staanspoor by sy mededosente ingeboesem het, blyk daaruit dat hy reeds in 1990 as plaasvervangende dekaan benoem word en in 1992 as dekaan van die Fakulteit Teologie (Afd A). Dit was nie alleen ' $n$ mosie van vertroue in sy akademiese en bestuursvermoë nie, maar ook in sy stabiele karakter en persoonlike eienskappe. Hy is gekies om die bootjịe van Afdeling A te stuur deur die troebel waters wat voorgelê het.

\section{HERSTRUKTURERING VAN DIE TEOLOGIESE OPLEIDING}

Die Fakulteit Teologie het aan die begin van die tagtigerjare met 'n herkurrikuleringsprojek begin wat uiteindelik ' $n$ groot bydrae tot die vernuwing van teologiese opleiding in die ou Afdeling A sou lewer. Dit is ook nie vergesog om te beweer dat die radikale herstrukturering van die Fakulteit Teologie en teologiese programme wat in 2000 begin realiseer het, van sy wortels in daardie aanvanklike herkurrikuleringsprojek gehad het nie.

Tydens 'n spesiale vergadering van Hervormde dosente op 7 September 1981 word besluit om 'n kurrikulumkomitee bestaande uit proff $P J$ van der Merwe, T F J Dreyer en dr J H Koekemoer saam te stel. Die feit dat laasgenoemde op daardie stadium slegs 'n tydelik-deeltydse verbintenis met die Fakulteit gehad het, het die vergadering nie gepla nie. Hy is gewoon as die mees geskikte persoon beskou, onder andere omdat hy op daardie stadium met die oog op die kategesehandboekprojek reeds 'n indringende studie van kurrikulumteorie gedoen het.

Die komitee besluit by sy eerste vergadering om ds PA Geyser te koöpteer en mnr Louis van Niekerk (op daardie stadium lidmaat van die Hervormde gemeente Philadelphia en in diens van die Afdeling Onderrigontwikkeling, UP) as tegniese raadgewer by sy werksaamhede te betrek. Die moeisame proses van indringende kurrikulumhersiening het hierna begin en sou vir baie jare daarna met wisselende tempo voortgaan, egter nie sonder dat verskeie belangrike aanpassings as gevolg van tussentydse aanbevelings van die komitee in Afdeling $A$ en die opleiding gemaak is nie.

In 1987 het prof J P Oberholzer dekaan van Afdeling A geword. Dit het 'n nuwe tydperk ingelei waartydens op indringende wyse oor die toekoms van die Hervormde Kerk se teologiese opleiding, asook van Afdeling A, besin is. 
Op 26 en 27 Mei 1988 vind die sogenaamde Espada-beraad plaas by 'n konferensie-oord oos van Pretoria. Johan Koekemoer moes as fasiliteerder optree. Dit was die eerste beraad waartydens indringend en omvangryk na die werklikhede van die teologiese opleiding gekyk is en die dosente kennis geneem het van die feit dat die bedeling soos dit op daardie stadium daar uitgesien het, reeds aan allerlei spanninge onderworpe was. Die dekaan het verduidelik dat die bestaan van "twee teologiese fakulteite" aan een universiteit al minder sin na buite uitgemaak het en dat dit allerweë deur ander dekane as dupliserend opgeneem word.

' $n$ Verdere saak wat by dieselfde beraad aan die orde gekom het, was die insinking in studentegetalle uit Afdeling A wat toe reeds voorsien is. Hoewel daar op daardie stadium nog nie 'n oorvoorsiening van proponente was, het die daling in die blanke geboortesyfer reeds so iets aangedui. Prof Oberholzer het vanaf die begin van die tagtigerjare statistiese berekenings gedoen wat daarop gedui het dat oorvoorsiening aan die einde van die dekade sou begin realiseer. Daar moes dus ook in terme van personeelrasionalisasie gedink word.

Hierna het verskeie verdere berade gevolg waarvan die belangrikste die volgende was:

- $\quad$ Fakulteitsberaad, Oswald Pirow-kamp, Nasionale Krugerwildtuin, 14 September 1990

- Fakulteitsberaad, Dirk van der Hoff-gebou en Teologiegebou, 1-2 Mei 1991

- $\quad$ Algemene beraad, Gemeente Villieria, 7-8 Oktober 1992

- Fakulteitsberaad, Orpen-kamp, Nasionale Krugerwildtuin, 12-13 Augustus 1993, voortgesit op 22-23 Sept 1993, Teologiegebou

- $\quad$ Algemene beraad, Teologiegebou, 13 Oktober 1993

- Algemene beraad, Hammanskraal, 20-21 Oktober 1995

- $\quad$ Fakulteitsberaad, Warmbad, 17-18 Oktober 1996

- $\quad$ Algemene beraad, Gemeente Villieria, 28 Augustus 1998

- $\quad$ Algemene beraad, Dirk van der Hoff-gebou, 19 en 20 Januarie 1999.

Prof Koekemoer se deelname en rol in hierdie proses van saampraat en -dink verander daadwerklik toe hy in 1992 as dekaan by prof Oberholzer oorneem. Gedurende 
1993 begin hy hom al meer ten gunste daarvan uitspreek dat die propedeutiese BA-studie vervang word met 'n BA(Teol). Die Dosentevergadering en Kuratorium besluit dan ook in 1994 om tot so ' $n$ stap oor te gaan en vanaf 1995 is begin om dit in te faseer. ${ }^{3}$

Hy het ook die frustrasie begin beleef dat dit van hom verwag is om leiding te gee in ' $n$ situasie waarvan die feitebeeld gedurig verander het (alhoewel die algemene tendens onmiskenbaar was). Met die sogenaamde Hammanskraalse beraad van 1995 is daar byvoorbeeld allerweë geglo dat die twee afdelings van die Fakulteit Teologie binnekort gedwing sou word om oor samesmelting te begin beraadslaag. Die prentjie verander egter met die aanstelling van prof Johan van Zyl, eers as viserektor vir Teologie en later as rektor van die Universiteit van Pretoria, wat hom aanvanklik ten gunste van twee fakulteitsafdelings uitspreek. Beide dosentevergadering en Kuratorium het begin wonder waarom daar vantevore soveel drukte oor 'n nuwe gesamentlike bedeling gemaak is.

Hierdie beeld word verskerp met die inligting wat tydens die sogenaamde Warmbadse beraad aan die dosente gegee is. Daar het hulle die indruk gekry dat die hoë publikasiekoers van Afdeling A hom nog lank in staat sou kon stel om te oorleef. Hierdie prentjie het egter kort daarna (in 1997) aan skerwe gespat toe die Universiteit van Pretoria begin het om 'n ingrypende rasionalisasieprogram in werking te stel op grond van ' $n$ drasties hersiene subsidieformule wat vir die volgende jaar verwag is. Skielik het begrotingstekorte orals begin opduik, onder andere in Afdeling A. Dat die subsidieformule uiteindelik nie so onvriendelik was as wat verwag is nie, het min gedoen om vrese te besweer. Almal het besef dat die skrif teen die muur was, veral omdat die Hervormde Teologiese Opleiding (Klipdrif) kort tevore deur 'n drastiese afskalingsproses moes gaan as gevolg van 'n drastiese rasionalisasie van sinodale strukture in die Nederduitsch Hervormde Kerk. Daar was dus geen hoop dat die kerk die situasie sou kon help beredder met subsidie nie. Vir die dekaan het 'n spanningsvolle tyd aangebreek.

Fen van die direkte gevolge van die finansiële rasionalisasieprogram was dat die Hoofbestuur van die Universiteit van Pretoria die twee fakulteitsafdelings gedurende 1997 versoek het om met samesprekings te begin met die oog op 'n samewerkingsmodel en 'n geamalgameerde fakulteit. Die eerste samesprekings het op 19 September 1997

\footnotetext{
3 Die ironie is dat die infasering in 2000 afgehandel is, dieselfde jaar waarin die teologiese leergang weereens ingrypend verander is.
} 
plaasgevind waar die volgende verteenwoordigers aanwesig was: proff $\mathrm{C} J$ Wethmar (voorsitter), J H Koekemoer, W S Prinsloo, A G van Aarde, P J van der Merwe en C J A Vos. Samesprekings het voortgeduur tot 4 Oktober 1999. Afdeling A het goed voorbereid in hierdie samesprekings ingegaan. Nie alleen het die berade wat vantevore gehou is, die dekaan en sy dosente die geleentheid gebied om die scenarios en saaklike argumente keer op keer te bedink en beredeneer nie, maar het dit hulle ook emosioneel voorberei om na ' $n$ nuwe bedeling oor te beweeg.

Daar was egter ook 'n tweede gevolg waarop hulle minder goed voorbereid was: dat vir die eerste keer in die lang geskiedenis van die Fakulteit Teologie ernstige oorweging verleen moes word aan die drastiese vermindering van doserende personeel.

Nadat die skrik van die eerste alarm oorgewaai het, het dit egter gou uit die samesprekings tussen die twee afdelings geblyk dat die ESS-basis van elke afdeling ' $n$ belangrike saak in toekomstige samesmelting sou wees. ${ }^{4}$ Afdeling A het toe reeds geweet dat hy hopeloos te min studente gehad het vir sy personeelgetal. Die situasie is vantevore grootliks beredder deur die relatief hoë publikasiekoers van sy dosente. In die nuwe situasie sou die ESS-verhouding egter deurslaggewend wees.

In die samesprekings is ooreengekom dat die Hervormde dosente in die Fakulteit self nie meer as ses sou uitmak nie. Op daardie stadium was daar twaalf Hervormde dosente in die Fakulteit. Die moeisame en pynlike proses om personeel te verminder moes begin.

Wanneer ' $n$ mens die notules van die verskillende vergaderings lees wat oor hierdie deel van die geskiedenis handel, kan 'n mens nie anders as om weer onder die indruk te kom van die pyn, selfs trauma, waarmee dit gepaard gegaan het nie. Allerlei planne is voorgestel om die skeiding vir die betrokkenes te versag, maar uiteindelik kon die pyn nie regtig verdoesel word nie. Uiteraard het diegene wat direk geraak is, dit die skerpste gevoel, maar uiteindelik het niemand gespaar gebly nie.

Professor Koekemoer het in hierdie tyd onder groot persoonlike spanning te staan gekom. Nie alleen vanweë deernis met kollegas wat skielik ernstige finansiële bekommernis gehad het nie, maar ook vanweë sy eie situasie, aangesien hy self ook een van die

\footnotetext{
${ }^{4}$ ESS: "effektiewe suksesvolle student."
} 
ses dosente sou wees wat die diens van die Universiteit van Pretoria voortydig moes verlaat. Dit kon nie anders as om 'n letsel op sy gesondheid te laat nie.

Hy het egter nooit toegelaat dat sulke persoonlike motiewe die groter belang van die Hervormde Kerk en meer in besonder die teologiese opleiding in gedrang bring nie. In die Dekanekomitee (wat as samesprekingsliggaam geskep is) het hy respek afgedwing met sy realiteitsin en regverdigheid, maar ook sy lojaliteit teenoor beide Hervormde Kerk en Universiteit. Van kleinlike politiek en kerkisme het hy so ver as moontlik probeer wegbly.

In die onderhandelings het hy hom sterk ten gunste van 'n kerklike kollege wat deur die Fakulteit Teologie geakkrediteer word, uitgespreek as 'n manier om kerklike vorming en praktykopleiding te waarborg. Hy help ook om dié struktuur te bedink en te beplan.

Die tweede fase in die geskiedenis van die Fakulteit Teologie het op 31 Desember 1999 tot 'n einde gekom toe die twee fakulteitsafdelings opgehou het om te bestaan. 5 ' $n$ Verdere effek daarvan was dat die afsonderlike dekaanskappe ook tot 'n einde gekom het. In Johan se geval was dit ook die datum waarop sy voltyds-permanente aanstelling afgesluit het. Soos in die geval van Moses was dit ook nie vir hom beskore om die beloofde land binne te gaan nie.

So het die nuwe Fakulteit Teologie dan op 1 Januarie 2000 begin. Vir die Hervormers sou dit die derde fase in die geskiedenis van die Fakulteit inlui. Weemoed oor wat verby is, was daar wel, maar so ook vooruitsig oor die belofte van die nuwe bedeling.

\section{OOR TEOLOGIE EN TEOLOGIESE OPLEIDING AS SODA- NIG}

Hieroor het hy hom reeds met sy intreerede uitgelaat toe hy gehandel het oor die moontlikheid van die beoefening van Dogmatiek binne die raamwerk van die konfessie. Hy sien die teoloog se verhouding met die konfessie as 'n normatiewe binding gekoppel met 'n hermeneutiese verantwoordelikheid. Die konfessie kan nie anders as om ook teen die agtergrond van sy histories-kulturele konteks verstaan te word nie, soos ook die uitsprake van teoloë. Diegene wat hoop om die konfessie soos 'n regsdokument te hanteer en af te

${ }^{5}$ Eerste fase: 1917-1937; iweede fase: 1938-1999; derde fase: 2000 -. 
dwing, het reeds vir ' $n$ legalistiese paradigma gekies en daarmee die Reformatoriese erfenis versaak.

Die konfessie verteenwoordig die gelowige verstaan en getuienis van vorige geslagte. Vir sover laasgenoemde deel uitmaak van die gemeenskap van gelowiges behoort dit ernstig geneem te word. Dit vorm trouens die basis van ons eie verstaan. Die tyd beweeg egter aan en elke geslag worstel met sy eie stel vrae. Vanselfsprekend is daar sekere vrae wat min of meer dieselfde bly. Daar kom egter ook nuwe vrae na vore waarop die konfessie nie noodwendig antwoorde bied nie. Die dogmatikus kan hierdie vrae nie onbeantwoord laat nie, maar moet sy of haar roeping nogtans in getrouheid teenoor Woord en Gees en in sensitiwiteit teenoor tradisie (wat konfessie insluit) en konteks nakom. Om dieselfde redes is dit onmoontlik dat Dogmatiek slegs apologeties beoefen kan word. Dit sou eweneens beteken dat die dogmatikus niks méér behoort te doen as om 'n vorige verstaan uit te lê of van toepassing te maak nie. Dit sou die dogmatikus ook aan betekenis en funksie vir sy dag en tyd ontneem.

Oor teologiese opleiding het hy hom by twee geleenthede veral uitgelaat, te wete die laaste akademiese opening van die Fakulteit Teologie (Afdeling A) op 25 Januarie 1999 en die eerste amptelike opening van die Hervormde Teologiese Kollege op 1 Februarie 2000. By eersgenoemde geleentheid pleit hy daarvoor dat teologiese opleiding 'n duideliker vormingsinslag moet kry, dat spiritualiteit trouens meer aandag in die opleiding moet ontvang. Hy spreek ook die frustrasie van baie dosente uit wanneer hy verwys na die papier- en administratiewe oorlog aan universiteite.

Tensy die kerk oortuig is dat die kerk se teoloë en hoogleraars sonder spiritualiteit kan funksioneer, sal die verbrokkeling van tyd wat deur 'n oormaat administrasie veroorsaak word, aangespreek moet word. 'n Oormaat van vergaderings en ander pligte het tot gevolg dat mense nie tyd het om te lees, te hoor en te mediteer, te dink en vrae en te deurdink nie. Daar is nie tyd vir bid en opbouende gesprek nie en studente word net masjiene wat punte versamel.

(Koekemoer 1999:332)

Hy verwys dus na die debat hier en oorsee oor die vraag of die universiteit steeds 'n geskikte omgewing uitmaak vir teologiese opleiding. Dit gaan oor die rigting wat die 
moderne universiteitswese inslaan, maar dit gaan ook oor die vraag waarheen met predikantsopleiding gemik moet word. Dit is ' $n$ gesprek wat tans op ' $n$ besondere en dringende wyse ook in die nuwe Fakulteit Teologie gevoer word.

Die tweede geleentheid was toe hy met die opening van die Hervormde Teologiese Kollege gepreek het na aanleiding van die verhaal van die Emmaüsgangers. Hy het onder andere gesê dat hulle nog so in hulle (onrealiseerbare) droom vasgevang was dat hulle nie in staat was om Jesus Christus langs hulle te herken nie. Dit was ironies dat hulle hulle teleurstelling en uitsigloosheid moes uitspreek teenoor Hom op wie hulle juis hulle hoop gevestig het. Op dieselfde wyse kan dit gebeur dat ons so vaskleef aan die droom van gister dat ons nie die geleenthede wat die Heer van die kerk aan ons in die nuwe situasie bied, raaksien nie. Hy het verder die waarskuwing gerig dat teologisering nie geloof waarborg nie en dat die teoloog 'n leeftyd met Jesus besig kan wees sonder om Hom waarlik te ken of te ontmoet. Jesus bly buite ons greep, maar kom diegene wat na Hom soek, tegemoet op oomblikke en maniere wat nie binne hulle beheer lê nie en wat hulle ook selde voorsien.

Ten slotte het hy die bede uitgespreek dat die Kollege voortdurend daarna sal trag om in die nabyheid van die Heer van die kerk te leef en werk, en dat Christus self die werk en verstaanspogings van hierdie instelling tegemoet sal kom.

\section{PUBLIKASIES}

\subsection{Proefskrif}

1972. Die Christologie van die Nuwe Teologie - 'n interpretasieprobleem, DD-proefskrif, Universiteit van Pretoria.

\subsection{Intreerede}

1989. Dogmatiek binne konfessionele verband.

\subsection{As promotor opgetree by doktorale proefskrifte: 2}

\subsection{Boeke: outeur en mede-outeur.}

Ek glo ('n uitleg van die Apostolicum), 1979. Kital. 
Handleiding vir ouderlinge, (red) 1979. Kital.

Handleiding vir diakens, (red) 1980. Kital.

'n Deugsame vrou, (red) 1981. Kital.

So glo ons, ('n verklaring van die Heidelbergse Kategismus), (medewerker) 1983. Kital.

Martin Luther 1483-1546, (red) 1984. Kital.

Ons doop ons kinders, (handleiding by doopkategese) (red) 1985. Kital.

Gemeentelike Evangelisasie - Toerustingsprogram, (medewerker), 1986. Kital.

Waar die paaie saamwoon. (medewerker), 1988. Potchefstroom.

\subsection{Betrokke by die persklaarmaak en uitgee van Kital-publikasies: 140.}

\subsection{Memoranda voorberei vir die Ned Hervormde Kerk: 8.}

\subsection{Wetenskaplike Artikels}

Die betekenis en plek van die hermeneutiek, 1966. HTS 22, 1-11.

Die Bybels-Reformatoriese teologie en die begrippe volk en nasionalisme, 1966. HTS $22,79-85$.

Die Afdeling Geloof en Kerkorde van die Wêreldraad van kerke, 1968. HTS 24, 12-19.

Die karakteristiek van die Arminianisme, 1969. HTS 25, 98-105.

Enkele opmerkings oor die Nuwe Teologie en meer bepaald sy Christologie, 1973. HTS $29,20-33$.

Die analitiese filosofie en moderne teologiese strominge, 1976. HTS 32, 126-135.

Geloofs- en gewetensbesware teen diensplig, 1982. Die Almanak 1(76), 26-29.

Luther en die predestinasie, in Martin Luther 1483-1546, 1984. Kital.

Die verbondstruktuur in die belydenisskrifte en formuliere, 1984. HTS 40, 100-105.

Die ekumene en rasseverhoudings, 1985. HTS 41, 89-103.

Die organiese inspirasieteorie binne die Gereformeerde tradisie, 1985. HTS 41, 104-107.

Catechesis in the light of Calvin's Institutes, in John Calvin's Institute: His Opus Magnum, 375-383. (Institute of International Studies.) 1986.

Die volkskerkvoorstelling in die Kerkwet van die Nederduitsch Hervormde Kerk van Afrika, 1987. HTS 4, 13-24. 
Die vraag na "verstaan" in die Christologie van D Bonhoeffer, 1988. HTS 44, 329-336.

Teologisering vir die gesekulariseerde mens, 1989. HTS 45, 401-411.

Resensie-artikel: De Gruchy J 1988, Dietrich Bonhoeffer: Witness to Jesus Christ, 1990 HTS 46, 458-460.

Die na-binne- of introverte gerigtheid van Kerk en Wêreld 2000, 1990. HTS 46, 708-715.

Die betekenis van die kerklike dogma, 1991. HTS 47, 186-196.

Vooronderstellings in die verstaansproses met spesifieke verwysing na Heinrich Ott se Christologiese model, 1991. HTS 47, 442-460.

Dogmatiek en Christelike Etiek binne die Fakulteit Teologie (Afd A) aan die Universiteit van Pretoria, 1992. HTS 48, 315-328.

Oop of geslote nagmaalviering? 'n Vraag aan die Nederduitsch Hervormde Kerk van Afrika, 1992. HTS 48, 815-825.

Metafoor, teologie, verbeelding: 'n Postmoderne beskouing, 1993. HTS 49, 595-608.

'n Kritiese evaluering van die Godsbeeld van Sally McFague, 1993. HTS 49, 235-254.

Die idioom van die Nederduitsch Hervormde Kerk - 'n teologiese vraag, 1994. HTS 50, 14-26.

Dogmatiek in die rigting van die Gereformeerde Ortodoksie? 1994. Skrif en Kerk 15, 87 94.

Die kerk as gebeure: 'n Dogmatiese perspektief, 1995. HTS 51, 595-603.

Die etos van die Nederduitsch Hervormde Kerk, 1995. HTS 51, 876-880.

Die uitdaging aan die teologiese opleiding in die NHKA en die HKSA, 1996. HTS 52, 190-196.

Dogma en kultuur, 1996. HTS 52, 734-745.

'n Inleidende woord deur die dekaan van die Fakulteit Teologie (Afd A), Universiteit van Pretoria en voorsitter van die redaksie van die Hervormde Teologiese Studies, 1997. HTS 53, 453-454.

Enkele motiewe vir 'n eietydse verstaan van die belydenisskrifte, 1997. HTS 53, 1321 1330.

Koekemoer, J H \& Groenewald A J. Nietzsche se uitspraak "God-is-dood" en die interpretasievoorstelle van Hans Küng en Jürgen Moltmann, 1998. HTS 54, 672-686. 
Koekemoer, J H \& Otto, J. 'n Soeke na menslikheid en Goddelikheid by Jesus: Chalcedon in die twintigste eeu verwoord, 1998. HTS 54, 789-809.

Die Heilige Gees en spiritualiteit in teologiese opleiding 1999. HTS 55, 322-333.

\subsection{Populêr-wetenskaplike artikels}

128 Artikels in Die Hervormer, Konteks, Die Transvaler en Beeld.

\section{Almanak}

1982, pp 26-29. Geloofs- en gewetensbesware teen diensplig. 1987, pp 27-29. Nederduitsch Hervormde Kerk as volkskerk. 1989, pp 14-17. Belydenisskrifte as kennisbron van die ouderling in sy amp. 1992, pp 46-47. Vroeëre professore aan die Fakulteit.

\section{Konteks}

1990, April, p 32. Geloof en lewe: Onverhoorde gebed? 1990, Mei, p 32. Geloof en lewe: Menslike lyding. 1990, Junie, p 32. Geloof en lewe: Wat beteken dit om in God te glo? 1990, Julie, p 32. Geloof en lewe: Hoekom het die kerk belydenisskrifte? 1990, Augustus, p 32. Geloof en lewe: Ons verwagting van Jesus Christus. 1990, September, p 32. Geloof en lewe: Sonde teen die Heilige Gees. 1990, Oktober, p 33. Geloof en lewe: Kan jy God in ' $n$ droom ontmoet? 1992, Oktober, 9. Ons voorgangers: Prof Ben Engelbrecht. 1994, Julie, pp 2-3. Voorbladartikel: Sondagviering. 1997, November, p 2. Voorbladartikel: Teologiese Fakulteit - gister, vandag en môre. 1997, November, p 5. Ek glo in God die Vader.

1999, September, p 6. Inspraak: Kommunikasie van geloof.

\section{Die Hervormer}

\section{Kital vraerubriek:}

1981, Januarie, Februarie, Maart, Mei, Junie, Julie, Augustus, September, Oktober, November, Desember; 
1982, Februarie, Maart, April, Mei, Junie, Julie, Augustus, September;

1983, Februarie, Maart, April, Junie, Julie, Oktober, Desember;

1984, Januarie, Maart.

\section{Bybelstudie:}

1984, April, Mei, Junie, Julie, Augustus, September, Oktober, November.

\section{Artikels:}

1981, Februarie, p 11. Delegering belangrike aspek van goeie bestuur.

1981, Mei, p 14. Niks sinistêrs aan dié kursus.

1981, Augustus, p 6. Ons moet die Heilige Gees nie vir reklame misbruik.

1982, Oktober, p 14. Hervormde stemme in Ottawa.

1982, November, p 1. Redaksioneel: Redes vir verbreking van bande.

1983, April (Vroue-Hervormer), p 1. Boodskap van Paasfees: Jesus lewe!

1983, Mei, p 8. Hemelvaart en ons toekomsverwagting.

1983, September, p 5. Hier word uit die Bybel gepraat.

1984, Januarie (Vroue-Hervormer), p 4. Luther se huwelik met Katharina von Bora.

1984, Mei, p 5. Nuwe Bybelse teologie?

1984 , November, p 7 . Wie en wat is die GES?

1984, November, p 3. GES en menseregte.

1986, November, p 16. Dietrich Bonhoeffer - 'n religielose Christendom vir die mondige mens.

1987, April, p 9. Wêreld van God in die Bybel.

1988, November, p 1. Belydenisskrifte en kategismusprediking bly vir die kerk onontbeerlik.

1990, 15 Julie, p 5. Aktuele sake aan die kerklike en teologiese front: Twyfel oor uitverkiesing onnodig.

1990, 1 September, p 5. Aktuele sake aan die kerklike en teologiese front: Kerk se belydenis nooit irrelevant nie.

1991, 1 Februarie, p 5. Aktuele sake aan die kerklike en teologiese front: Nederduitsch Hervormde Kerk en ekumeniese byeenkomste. 
1991, 1 Desember, p 5. Aktuele sake aan die kerklike en teologiese front: Is geloof die enigste voorwaarde vir lidmaatskap van die kerk?

1992, 1 Mei, p 5. Aktuele sake aan die kerklike en teologiese front: Gesprek oor God is 'n gesprek met God.

1992, 1 Oktober, p 5. Aktuele sake aan die kerklike en teologiese front: Broeder C J Kruger se bedanking - 'n ernstige vraag aan hom.

1993, 1 September, pp 3, 7. Kommentaar: Teologie wil lidmate nie verwar.

1993, 1 September, p 6. Briewe van ons lesers: Studente moet nie so negatief beoordeel word.

1994, 1 Februarie, p 6. Nog 'n ooreenkoms met UP in diens van predikanteopleiding en teologiese navorsing.

1994, 1 Julie, p 1. Jubileumviering van Hervormde Teologiese Studies.

1994, 1 Desember, p 3. Op soek na 'n evangeliese teologie.

1995, 1 Maart p 5. Aktuele sake aan die kerklike en teologiese front: Teologiese Fakulteit - die toekoms.

1995, 15 Desember, pp 1,6. Wonder van Kersfees.

1996, 15 Julie, p 3. Prof BJ Engelbrecht - 'n huldigingswoord.

1996, 1 November, p 4. Lig uit die Woord: Romeine 8:31-39 - Ek glo ...

1997, 15 April, p 5. Kerk en teologie: Voortgesette opleiding van predikante.

1997, 1 September, p 3. Eerste in Afrikaans: Immanuel Kant se Grundlegung zur Metaphysik der Sitten.

1999, 1 Maart, p 5. In diepte ... Heilige Gees, spiritualiteit en teologiese opleiding.

1999, 1 Oktober, p 14. Die Hervormer 1899-1999: 'n Eeu in diens van die Kerk en gemeenskap.

1999, 15 Oktober, p 14. Die Hervormer 1899-1999: Die Hervormer as klankbord van die Hervormde teologie.

1999, 1 Desember, pp 5, 8. Die Hervormer 1899-1999: Hervormde teologie in die twintigste eeu.

2000, 1 Maart, p 4. Lig uit die Woord: Lukas 24:13-35 - Ons hoop ... Jesus Christus. 


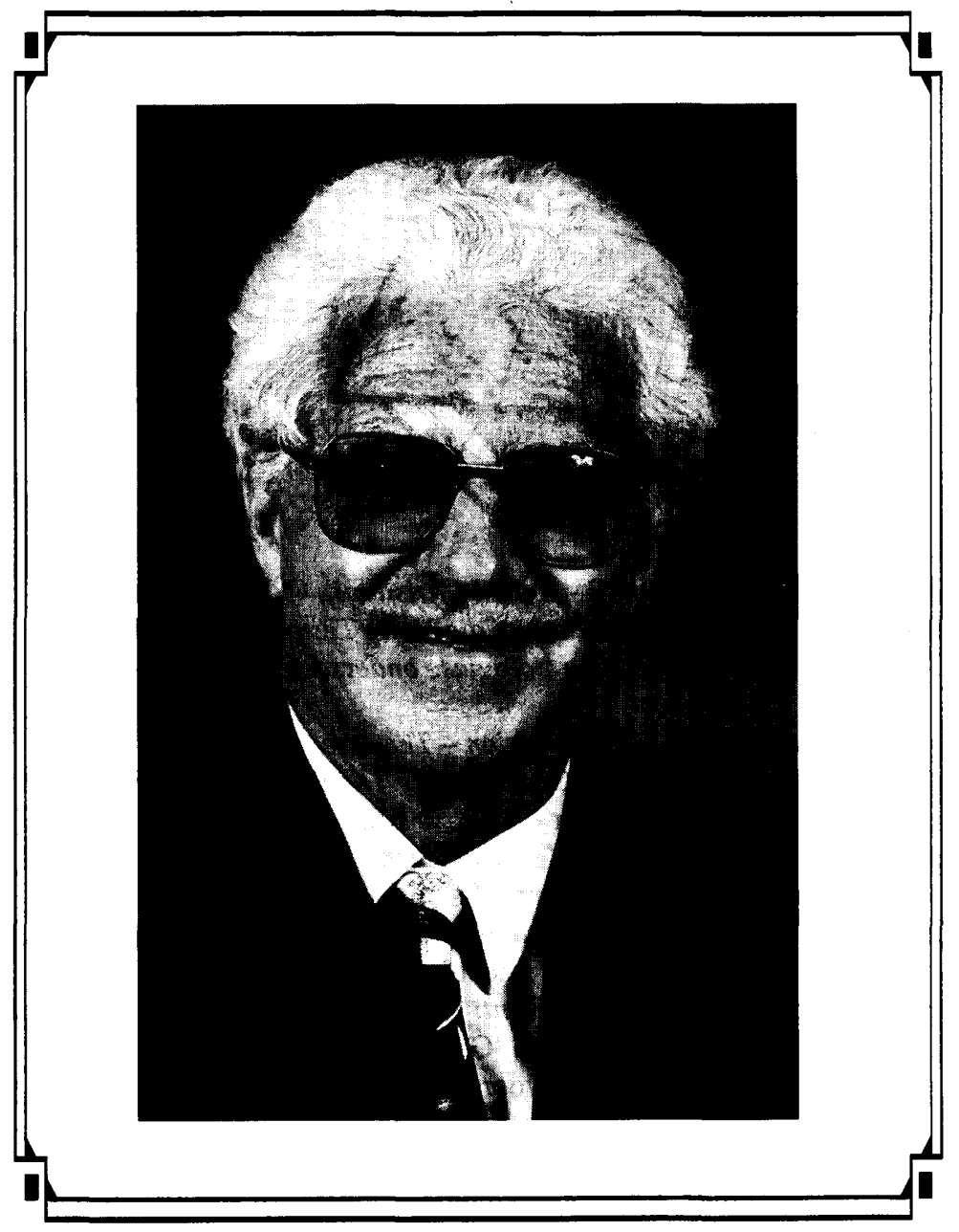

Prof dr J H Koekemoer 